\title{
The Relationships between Website Reputation, Website Quality, and Repeat Purchase Intention: The Moderating Effect of Trust
}

\author{
Wen-Hai Chih ${ }^{1 *}$, Mingzhe Ren ${ }^{1,2}$ \\ ${ }^{1}$ Department of Business Administration, National Dong Hwa University, China \\ ${ }^{2}$ Department of Business Administration, Business School, and Guangdong Coastal Economic Belt Development Research Center, \\ Lingnan Normal University, Zhanjiang, China \\ Email: *whchih@gms.ndhu.edu.tw, renmingzhe@163.com
}

How to cite this paper: Chih, W.-H., \& Ren, M. Z. (2020). The Relationships between Website Reputation, Website Quality, and Repeat Purchase Intention: The Moderating Effect of Trust. Open Journal of Social Sciences, 8, 507-513.

https://doi.org/10.4236/jss.2020.83043

Received: March 14, 2020

Accepted: March 28, 2020

Published: March 31, 2020

\begin{abstract}
The purpose of this study is to explore the relationships between website reputation, website quality, and repeat purchase intention and the moderating effect of trust on the relationship between website reputation and website quality. Results show that website reputation has a significant and positive effect on website quality, which also has a significant and positive effect on repeat purchase intention. However, trust does not moderate the relationship between website reputation and website quality.
\end{abstract}

\section{Keywords}

Website Reputation, Website Quality, Repeat Purchase Intention, Trust

\section{Introduction}

In the context of e-commerce, pre-purchase, on-line, and post sales are three phases of marketing based on the functions and features of websites (Liu \& Arnett, 2000). Consumers search product information, complete online payments, and fulfill purchases through a website (Zhang, Fang, Wei, Ramsey, McCole, \& Chen, 2011). Thus customers rely on website for their online transactions. Prior studies investigated the relationships between website reputation, trust, and website quality (Hsu, Chang, Chu, \& Lee, 2014; Park, Gunn, \& Han, 2012) as well as the relationship between user-perceived website quality and trust (Liao, Palvia, \& Lin, 2006). It comes out the following research questions: Does website 
reputation enhance consumers' perceptions of website quality and does trust moderate this relationship? If so, how about this relationship? Thus, this study explores the effect of website reputation on website quality and the moderating effect of trust on this relationship.

\section{Theoretical Foundations and Research Model}

\subsection{Website Reputation}

Website reputation is defined as "customers believe that a seller/website is honest and concern about its customer" (Hsu et al., 2014, p. 238). Websites with reputation are more likely to provide objective information rather than false reviews to their customers and care about their customers' benefits by delivering values to them (Hsu et al., 2014). Thus, consumers can receive credible information from a website with good reputation and perceive its product's value (Sullivan \& Kim, 2018), which increases consumers' benefits in transaction process, reduces search time, and creates convenient communication. A website's reputation has a significant effect on consumers' trust (Kim \& Park, 2013).

\subsection{Website Quality}

Website quality influences customer's purchase decisions (Liao et al., 2006). A well-designed website provides high quality to make easy navigation to consumers and increase their online purchasing experiences and their evaluations (Zhang et al., 2011). In addition, website quality indicates high information quality, quick response time, and high visual attractiveness (Liao et al., 2006). Consumers are eager to easily find the information and clearly communicate with online vendors via high quality of website. Website quality significantly improves customers' satisfaction (Kim \& Peterson, 2017; Zhang et al., 2011). Therefore, we hypothesize that:

H1: Website reputation has a significant and positive effect on website quality.

\subsection{Repeat Purchase Intention}

Repeat purchase intention is related to the probability that consumers will continuously purchase from the same website. It reflects continuous purchasing behavior in online context. Website quality is a key factor of motivating consumers in shopping process (Chou \& Hsu, 2016) and guarantees accuracy, completeness, currency, and format (Kim \& Peterson, 2017). Consumers can quickly find necessary information in the website to reduce time cost. This can facilitate consumers to perceive reliable and convenient website to fulfill their purchases. Furthermore, quick response time leads consumers to experience more meticulous and thoughtful services. High attractive and visual website induces consumers' desires to browse it. Therefore, a successful website can attract customers, increase their perceptions of reliability, and improve their satisfaction (Liu \& Arnett, 2000). Moreover, satisfaction positively influences customers' intentions in online shopping context (Chou \& Hsu, 2016). Thus, satisfaction influences 
consumers' repeat purchase intentions. Therefore, we hypothesize that:

$\mathrm{H} 2$ : Website quality has a significant and positive effect on repeat purchase intention.

\subsection{Trust}

"Trust refers to one's belief that others in an exchange will not act opportunistically by taking advantage of the situation" (Hsu et al., 2014, p. 237) and includes ability, benevolence, and integrity (Pavlou \& Fygenson, 2006). Ability refers to a set of characteristics, competencies, and skills within some specific domain. Benevolence refers to an exchange partner is willing to keep customers' interests (Hallikainen \& Laukkanen, 2018). Integrity is an individual's perception that a partner adheres to a series of principles in an exchange process. A well-designed website with simple navigation improves its ability to affect its consumers' perceptions of quality (Zhang et al., 2011). Benevolence reduces social uncertainty by ruling out undesirable behavior (i.e., opportunistic behavior) (Gefen \& Straub, 2004). Website possesses a large amount of consumers' personal information. Consumers may face the risk of information theft and corruption data due to the opportunistic behavior of websites. Privacy risk is one of the most salient factors which consumers concern (Featherman, Miyazaki, \& Sprott, 2008). A trustworthy website cares about its consumers' interests. Integrity reflects the perception of one party toward another party as being honest, acting ethic, fulfilling its promises, making faith agreements, and telling the truth (Hallikainen \& Laukkanen, 2018). Consumers are more likely to believe online vendors who keep their promises. They expect that online vendors will behave reliably and protect their personal information to reduce risk in the website. Comments and rating in the feedback-based website decide its trustworthiness (Hsu et al., 2014). Thus, website reputation is related to trust.

Intermediary trust and seller trust are two types of trust in the online shopping context. Intermediary trust is regarding the trustworthiness of a website (Hsu et al., 2014). Consumers and vendors conduct their transactions on the website which is the intermediary between them. A website with accurate and objective information about vendors and their products increases consumers' trust. Consumers generate positive attitude and enhance high level of quality perception toward high level of trust. Conversely, low level of trust mitigates quality perception (Hsu et al., 2014). Thus, trust beliefs determine the perception of website quality (Hsu et al., 2014). Therefore, we hypothesize that:

H3: Trust moderates the relationship between website reputation and website quality.

Figure 1 shows the proposed model.

\section{Methods}

\subsection{Measure Development}

Scales were adopted from previous studies. Scales for website reputation and 


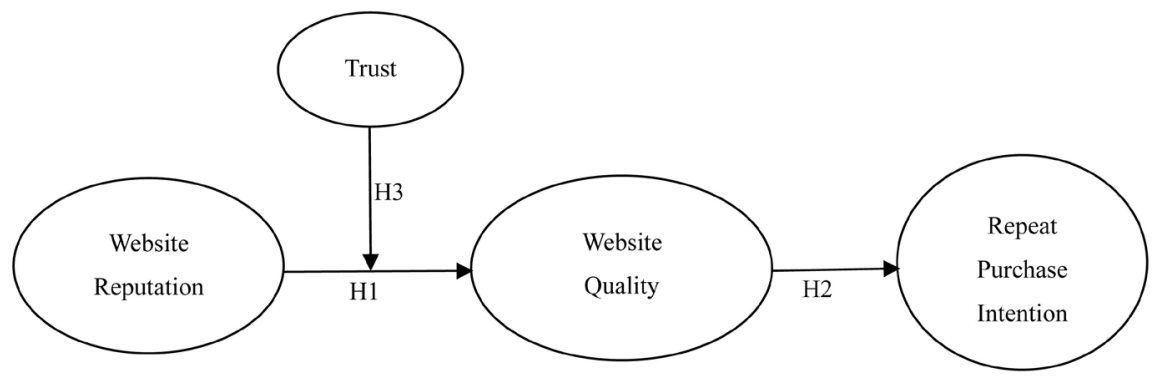

Figure 1. Proposed research model.

website quality were derived from Kim and Park (2013) and Park et al. (2012), respectively. Scales for repeat purchase intention and trust were derived from Chiu, Hsu, Lai, and Chang (2012). This study adopted a 7-point Likert scale (1 for strongly disagree and 7 for strongly agree) for all items and conducted pretest to ensure the appropriate wording of items.

\subsection{Samples}

All respondents are undergraduate students in Guangdong, China. Each respondent had shopping experience on Jingdong website in China. A total of 314 samples were collected with 225 valid samples.

\subsection{Common Method Variance}

This study adopted prevention and post-detection procedures to mitigate the common method variance (CMV) problem. For prevention procedure, we randomized the constructs in the questionnaire. For post-detection procedure, we adopted Harman's single-factor analysis to check CMV problem (Podsakoff, MacKenzie, Lee, \& Podsakoff, 2003). The explained variance for the first factor of Harman's single-factor analysis is $49.18 \%$. Thus, CMV problem is not concerned in this study.

\section{Results}

We conducted the measurement model and structural model (Anderson \& Gerbing, 1988) with AMOS 20.0 versions software to analyzed data. The results of measurement model indicated that the factor loadings of all items were higher than 0.5 (Hair Jr., Black, Babin, \& Anderson, 2010), the values of composite reliability and Cronbach alpha of all constructs were higher than 0.70 (Fornell \& Larcker, 1981; Nunnally, 1979), and the average variance extracted (AVE) of all constructs were above 0.5 (Fornell \& Larcker, 1981). The square roots of AVE for all constructs were greater than the correlations with other constructs. It indicated the for the discriminant validity. Thus, the results demonstrated sufficient validity and reliability.

The results of the structural model showed an acceptable model fit: $\chi^{2}=$ 76.249, $\mathrm{df}=33, \chi^{2} / \mathrm{df}=2.311$, Goodness-of-fit index $(\mathrm{GFI})=0.934$, Tucker-Lewis index $(\mathrm{TLI})=0.948$, Comparative fit index $(\mathrm{CFI})=0.962$, Nonnormed fit index 
$(\mathrm{NFI})=0.936$, Incremental fit index $(\mathrm{IFI})=0.962$, Parsimonious normed-fit in$\operatorname{dex}(\mathrm{PNFI})=0.686$, Root mean square error of approximation (RMSEA) $=$ 0.076. In addition, structural model analyzed the path coefficients of research hypotheses and the results confirmed that website reputation has a significant and positive effect on website quality, which has a significant and positive effect on repeat purchase intention. The $\mathrm{R}^{2}$ values are $32.3 \%$ and $40.1 \%$ for website quality and repeat purchase intention, respectively. Figure 2 shows the results of structural model.

This study adopted the conditional process model (Hayes, 2013; Hayes, Montoya, \& Rockwood, 2017) to analyze the moderating effect of trust. The results indicated trust does not moderate the relationship between website reputation and website quality $(\mathrm{t}=0.671, p>0.05)$. Figure 3 shows the conditional effect of trust.

\section{Conclusion}

This study explored the relationships between website reputation, website quality, repeat purchase intention, and trust. Website reputation increases website quality, which improves consumers' repeat purchase intentions. However, trust does not moderate the relationship between website reputation and website quality. Theoretically, trust does not moderate the relationship between website reputation and website quality although website reputation influences trust, which influences website quality (Hsu et al., 2014). Practically, website managers should enhance their website reputation to increase their website quality in order to improve consumers' repeat purchase intentions.

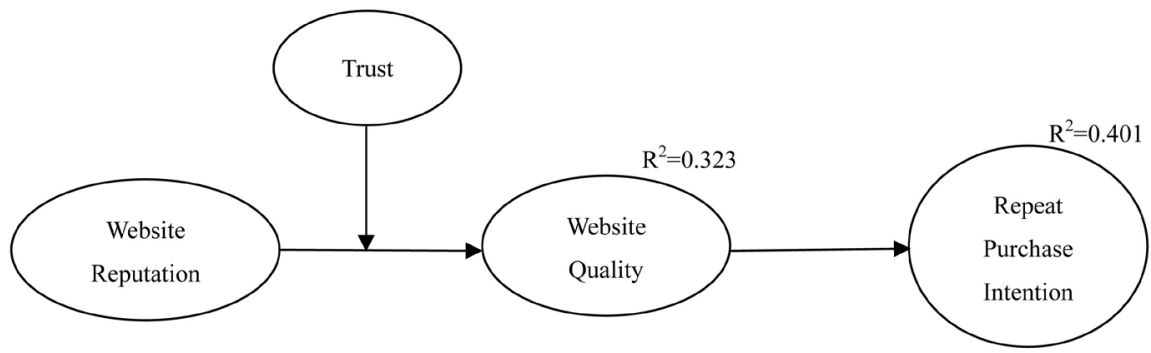

Figure 2. Research model results.

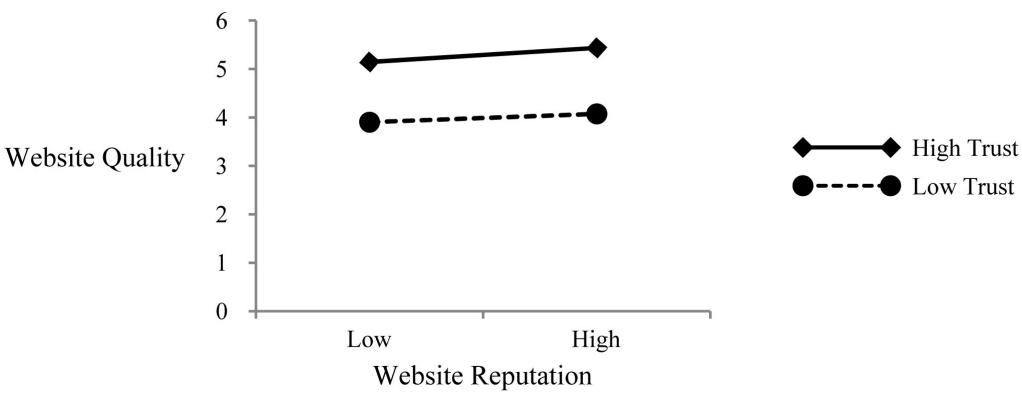

Figure 3. Conditional effect of trust on the relationship between website reputation and website quality 


\section{Conflicts of Interest}

The authors declare no conflicts of interest regarding the publication of this paper.

\section{References}

Anderson, J. C., \& Gerbing, D. W. (1988). Structural Equation Modeling in Practice: A Review and Recommended Two-Step Approach. Psychological Bulletin, 103, 411-423. https://doi.org/10.1037/0033-2909.103.3.411

Chiu, C. M., Hsu, M. H., Lai, H. C., \& Chang, C. M. (2012). Re-Examining the Influence of Trust on Online Repeat Purchase Intention: The Moderating Role of Habit and Its Antecedents. Decision Support Systems, 53, 835-845. https://doi.org/10.1016/j.dss.2012.05.021

Chou, S. W., \& Hsu, C. S. (2016). Understanding Online Repurchase Intention: Social Exchange Theory and Shopping Habit. Information Systems and E-Business Management, 14, 19-45. https://doi.org/10.1007/s10257-015-0272-9

Featherman, M. S., Miyazaki, A. D., \& Sprott, D. E. (2008). Reducing Online Privacy Risk to Facilitate E-Service Adoption: The Influence of Perceived Ease of Use and Corporate Credibility. Journal of Services Marketing, 24, 219-229.

https://doi.org/10.1108/08876041011040622

Fornell, C., \& Larcker, D. F. (1981). Evaluating Structural Equation Models with Unobservables and Measurement Error. Journal of Marketing Research, 18, 39-50. https://doi.org/10.1177/002224378101800104

Gefen, D., \& Straub, D. W. (2004). Consumer Trust in B2C E-Commerce and the Importance of Social Presence: Experiments in E-Products and E-Services. Omega, 32, 407-424. https://doi.org/10.1016/j.omega.2004.01.006

Hair Jr., J. F., Black, W. C., Babin, B. J., \& Anderson, R. E. (2010). Multivariate Data Analysis (7th Ed.). Upper Saddle River, NJ: Pearson Prentice-Hall.

Hallikainen, H., \& Laukkanen, H. (2018). National Culture and Consumer Trust in E-Commerce. International Journal of Information Management, 38, 97-106. https://doi.org/10.1016/j.ijinfomgt.2017.07.002

Hayes, A. F. (2013). Introduction to Mediation, Moderation, and Conditional Process Analysis: A Regression-Based Approach. New York, NY: Guilford Press.

Hayes, A. F., Montoya, A. K., \& Rockwood, N. J. (2017). The Analysis of Mechanisms and Their Contingencies: Process versus Structural Equation Modeling. Australasian Marketing Journal, 25, 76-81. https://doi.org/10.1016/j.ausmj.2017.02.001

Hsu, M., Chang, C., Chu, K., \& Lee, Y. (2014). Determinants of Repurchase Intention in Online Group-Buying: The Perspectives of DeLone \& McLean IS Success Model and Trust. Computers in Human Behavior, 36, 234-245. https://doi.org/10.1016/j.chb.2014.03.065

Kim, S., \& Park, H. (2013). Effects of Various Characteristics of Social Commerce (S-Commerce) on Consumers' Trust and Trust Performance. International Journal of Information Management, 33, 318-332. https://doi.org/10.1016/j.ijinfomgt.2012.11.006

Kim, Y., \& Peterson, R. A. (2017). A Meta-Analysis of Online Trust Relationships in E-Commerce. Journal of Interactive Marketing, 38, 44-54. https://doi.org/10.1016/j.intmar.2017.01.001

Liao, C., Palvia, P., \& Lin, H.-N. (2006). The Roles of Habit and Web Site Quality in E-Commerce. International Journal of Information Management, 26, 469-483. 
https://doi.org/10.1016/j.ijinfomgt.2006.09.001

Liu, C., \& Arnett, K. P. (2000). Exploring the Factors Associated with Web Site Success in the Context of Electronic Commerce. Information \& Management, 38, 23-33.

https://doi.org/10.1016/S0378-7206(00)00049-5

Nunnally, J. C. (1979). Psychometric Theory. New York, NY: McGraw-Hill.

Park, J. K., Gunn, F., \& Han, S.-L. (2012). Multidimensional Trust Building in E-Retailing: Cross-Cultural Differences in Trust Formation and Implications for Perceived Risk. Journal of Retailing and Consumer Services, 19, 304-312. https://doi.org/10.1016/j.jretconser.2012.03.003

Pavlou, P. A., \& Fygenson, M. (2006). Understanding and Predicting Electronic Commerce Adoption: An Extension of the Theory of Planned Behavior. MIS Quarterly, 30, 115-143. https://doi.org/10.2307/25148720

Podsakoff, P. M., MacKenzie, S. B., Lee, J.-Y., \& Podsakoff, N. P. (2003). Common Method Biases in Behavioral Research: A Critical Review of the Literature and Recommended Remedies. Journal of Applied Psychology, 88, 879-903.

https://doi.org/10.1037/0021-9010.88.5.879

Sullivan, Y., \& Kim, D. (2018). Assessing the Effects of Consumers' Product Evaluations and Trust on Repurchase Intention in E-Commerce Environments. International Journal of Information Management, 39, 199-219.

https://doi.org/10.1016/j.ijinfomgt.2017.12.008

Zhang, Y. X., Fang, Y. L., Wei, K. K., Ramsey, E., McCole, P., \& Chen, H. P. (2011). Repurchase Intention in B2C E-Commerce: A Relationship Quality Perspective. Information \& Management, 48, 192-200. https://doi.org/10.1016/j.im.2011.05.003 